\title{
Resource Use Efficiency on Wheat Cultivation in Auraiya District of Western Uttar Pradesh, India
}

\author{
R.R. Kushwaha ${ }^{1}$, K.K. Mourya ${ }^{2}$, R.R. Verma ${ }^{1}$, Bhim Singh ${ }^{3 *}$, \\ Sugriv Kumar Maurya ${ }^{4}$, Neeraj Kumar ${ }^{1}$ and Sarvesh Kumar ${ }^{2}$
}

${ }^{1}$ Department of Agriculture Economics, ${ }^{2}$ Department of Agriculture Statistics, N.D. University

of Agriculture and Technology, Faizabad, U.P., India

${ }^{3}$ Department of Basic Science, College of Horticulture of Forestry (AU Kota), Jhalawar, Rajasthan, India

${ }^{4}$ Janta Mahavidyalaya Ajeetmal, Auraiya (U.P.), India

*Corresponding author

\section{A B S T R A C T}

\begin{tabular}{|l|}
\hline K e y w o r d s \\
$\begin{array}{l}\text { Cobb-Douglas production } \\
\text { function, Cropping } \\
\text { intensity, Efficiency, } \\
\text { Wheat }\end{array}$ \\
\hline Article Info \\
\hline $\begin{array}{l}\text { Accepted: } \\
\text { 06 May } 2018 \\
\text { Available Online: } \\
\text { 10 June } 2018\end{array}$ \\
\hline
\end{tabular}

\section{Introduction}

Wheat is the world's most widely cultivated staple food crop being grown since prehistoric period and being consumed in various farmers by more than one thousand (1000) million in the world. Wheat plays an important role in shaping agriculture and food security mission. India is the second largest producer of wheat next to China. The area under wheat in India was reported 31.20 million hectare

\begin{abstract}
In the present paper an attempt has been made to examine the resources use efficiency of wheat cultivation in Auraiya district of western Uttar Pradesh. The study covered five villages of Auraiya district and hundred sample farmers (Marginal, Small and Medium) were interviewed from five villages of Bhagya Nagar block of Auraiya district (U.P.) to work out cropping pattern and cropping intensity along with the cost of cultivation and profit measures on wheat crop of sample farms. Data ware analyzed and found that average holding size was 0.818 hectare and cropping intensity was 216.04 percent, wheat occupied 32.05 percent of gross cropped area, it offers a net income of ₹ 15796.23 with an expenditure of ₹ 48691.13 as total cost per hectare. Input-output ratio was found 1:1.32 on over all farms having direct related with size of holding wheat cultivation in the study area characterized by decreasing return to scale.
\end{abstract}


million agricultural households in the state and approximately 59 percent of its workforce was dependent on agriculture for a livelihood in 2011 (as per NSS 2012-13; and Census 2011). Marginal ( $<1 \mathrm{ha})$ and small (1-2 ha) farmers cultivate 92.5 percent of all landholdings in UP which accounts for 64.8 percent of the total area cultivated in UP. Average monthly income of an agricultural household in UP is third lowest (₹ 4701) in the country and the state also accounts for the largest share (16.9 percent) of all indebted agricultural households in India - 90.4 percent of these being marginal and small agricultural households (Agricultural Statistics at a Glance, 2015).

Auraiya district is also an important wheat producing district of U.P. the area under wheat in the district during 2013-14 was reported 102892 hectare with production of 39599900 quintal while productivity was 38.48 qt/ha. (Arth evam Sankhiya Prabhag, Auraiya district, U.P., 2013-14). Keeping this in view proposed study entitled "Resource use efficiency on wheat cultivation in Auraiya district of western Uttar Pradesh" assumes special significance. The main objectives of the study were:

To work out cropping pattern and cropping intensity of sample farms.

To work out the cost of cultivation and profit measures of wheat crop on sample farms.

\section{Materials and Methods}

\section{Selection of sample farmers}

A separate list of paddy growers of five villages was prepared along with their size of holding and classified in to three categories i.e. (i) Marginal (Below 1 ha.), (ii) Small (1 to 2 ha), and (iii) Medium (2 to 4) multistage stratified purposive cum random sampling technique was used to select the district, block, village and farmers. Auraiya district was selected purposively. A list of all blocks was prepared on the basis of acreage in paddy and "Bhagya Nagar" block was selected randomly.

\section{Methods of enquiry}

The primary data were collected by survey method through personal interview with use of pre structured and pre-tested schedule, while secondary data were collected from (Zila sankhiki patrika, Auraiya district, U.P.) Agriculture Department, block head quarter, journals, reports, books and internet etc.

\section{Analysis of data}

Tabular analysis was used for analysis of data weighted average; Cropping intensity and cost benefit ratio were worked out with the following formula.

Weight Average (W.A.) $=\sum \mathrm{W}_{\mathrm{i}} \mathrm{X}_{\mathrm{i}} / \sum \mathrm{w}_{\mathrm{i}}$

$$
\begin{aligned}
& \text { Cropping Intensity } \\
& =\frac{\text { Total cropped area }}{\text { Net Cultivated area }} \times 100
\end{aligned}
$$

\section{Regression analysis}

Cobb-Douglas production function was applied to study the resource use efficiencies in wheat production. The mathematical from of Cobb-Douglas production function (Cobb and Douglas, 1928) is

$Y=a x_{1}^{b 1} X_{2}^{b 2} X_{3}^{b 3} X_{4}^{b 4} C_{\mu}$

Where,

$\mathrm{Y}=$ Per hectare output (₹/ha.)

$\mathrm{X}_{1}=$ Seed change (₹/ha.)

$\mathrm{X}_{2}=$ Manure and fertilizers 
$\mathrm{X}_{3}=$ Irrigation

$\mathrm{X}_{4}=$ Human Labour

$\mathrm{A}=$ Constant

$b_{1}=(i=1,2,3$ and 4$)$ elasticity coefficient of the respective input variable.

$\mathrm{E}=$ Error term

$\mu=$ Random variable

log form of the cob- Douglas production function was used for estimating the parameter of the faction based on simple data.

$\log X=\log a+b_{1} \log x_{1}+b_{2} \log x_{2}+b_{3} \log x_{3}$ $+b_{4} \log x_{4} \ldots \ldots \ldots \ldots \ldots \ldots \mu$ log e.

\section{Marginal value product (MVP)}

The marginal value product of input was estimated by taking partial derivatives to return with respect to input concerned, at the geometric mean level of input.

$\operatorname{MVP}\left(\mathrm{b}_{\mathrm{i}}\right)=\frac{b_{i} \bar{y}}{\bar{X}_{i}}$

Where,

$b_{i}=$ Production elasticity with respect to $X_{i}$

$\bar{y}=$ Geometric mean of $y$ (output values in ₹/ha)

$\bar{X}_{i}=$ Geometric mean of $X_{\mathrm{i}}$ (input values in ₹ /ha)

\section{Results and Discussion}

\section{Farm structure}

Farm structure includes the average size of holding, cropping intensity cropping pattern and investment on farm assets.

\section{Size of holding}

The average size of holding and cropping intensity are presented in Table 1.

It is depicted from the table that average holding size on overall farm was 0.818 hectare which was a minimum of 0.47 hectare at marginal farms and maximum of 2.25 hectare at medium farms. The holding size at small and medium farms of study area were found 0.47 to 1.24 and 2.25 hectare respectively

\section{Cropping intensity}

Cropping intensity as a ratio between gross cropped area and Net sown area expressed in percentage in presented in Table 1.

The maximum cropping intensity on overall farm was observed to 219.55 percent in case of medium farm, followed by small, marginal farms corresponding to 213.70 and 214.84 percent respectively with an overall average of 216.04 percent.

Cropping Intensity $=\frac{\text { Total Cropped Area }}{\text { Net sown Area }} \times 100$ or

C.I. $\%=\frac{1.75}{0.81} \times 100=216.04 \%$

\section{Cropping pattern}

Cropping pattern is the proportion of area under different crops at a point of time. It is an important factor to decide the level of investment for different input on a farm; and income of farmer based on resource availability and climatic condition Table 2 presents the position of cropping pattern followed by sample farmer of different category. Wheat was found as a major crop occupying 32.056 percent of total cropped area. 
Table.1 Average size of holding on sample farms under different size group of farms (Area in ha.)

\begin{tabular}{|c|c|c|c|c|c|c|}
\hline S. $\mathbf{N}$. & $\begin{array}{c}\text { Category of } \\
\text { Farms }\end{array}$ & $\begin{array}{l}\text { No. of } \\
\text { sample } \\
\text { Farms }\end{array}$ & $\begin{array}{l}\text { Net Sown } \\
\text { Area (ha) }\end{array}$ & $\begin{array}{c}\text { Average } \\
\text { size of } \\
\text { holding (ha) }\end{array}$ & $\begin{array}{l}\text { Cross cropped } \\
\text { area (ha) }\end{array}$ & $\begin{array}{c}\text { Cropping } \\
\text { intensity }(\%)\end{array}$ \\
\hline 1 & $\begin{array}{c}\text { Marginal (below } \\
-1 \text { ha) }\end{array}$ & 67 & $31.697(38.71)$ & 0.473 & 1.01 & 214.89 \\
\hline 2 & Small (1 to $2 \mathrm{ha}$ ) & 24 & $29.857(36.69)$ & 1.244 & 2.65 & 213.70 \\
\hline 3 & $\begin{array}{c}\text { Medium (2 to } 4 \\
\text { ha) }\end{array}$ & 09 & $20.329(24.82)$ & 2.258 & 4.94 & 219.55 \\
\hline 4 & Overall & 100 & $81.883(100)$ & 0.8188 & 1.75 & 216.04 \\
\hline
\end{tabular}

Table. 2 Cropping pattern on different size of sample farms

\begin{tabular}{|c|c|c|c|c|c|c|c|c|c|}
\hline \multirow{3}{*}{$\begin{array}{l}\text { S.N. } \\
\text { (A) }\end{array}$} & \multirow{3}{*}{$\begin{array}{c}\text { Name of Crops } \\
\text { Costs }\end{array}$} & \multicolumn{8}{|c|}{ Size group of farmers } \\
\hline & & \multicolumn{2}{|c|}{ Marginal } & \multicolumn{2}{|c|}{ Small } & \multicolumn{2}{|c|}{ Medium } & \multicolumn{2}{|c|}{ Overall average } \\
\hline & & $\begin{array}{l}\text { Area in } \\
\text { (ha) }\end{array}$ & $\%$ & $\begin{array}{l}\text { Area in } \\
\text { (ha) }\end{array}$ & $\%$ & $\begin{array}{l}\text { Area in } \\
\text { (ha) }\end{array}$ & $\%$ & $\begin{array}{l}\text { Area in } \\
\text { (ha) }\end{array}$ & $\%$ \\
\hline 1 & Wheat & 0.349 & 34.1 & 0.827 & 31.18 & 1.438 & 29.10 & 0.561 & 32.05 \\
\hline 2 & Bajara & 0.274 & 27.12 & 0.691 & 26.02 & 1.117 & 22.61 & 0.44 & 25.14 \\
\hline 3 & Maize & 0.054 & 5.34 & 0.204 & 7.68 & 0.462 & 9.35 & 0.127 & 7.25 \\
\hline 4 & Paddy & 0.072 & 7.12 & 0.162 & 6.10 & 0.389 & 7.89 & 0.122 & 6.97 \\
\hline 5 & Moong or Urad & 0.052 & 5.14 & 0.118 & 4.44 & 0.287 & 5.80 & 0.099 & 5.65 \\
\hline 6 & Potato & 0.042 & 4.15 & 0.126 & 4.74 & 0.453 & 9.17 & 0.098 & 5.60 \\
\hline 7 & Jowar & 0.052 & 5.14 & 0.085 & 3.20 & 0.152 & 3.07 & 0.069 & 3.94 \\
\hline 8 & Mustard & 0.037 & 3.66 & 0.095 & 3.57 & 0.115 & 2.32 & 0.058 & 3.31 \\
\hline 9 & Gram & 0.018 & 1.78 & 0.112 & 4.21 & 0.056 & 1.13 & 0.044 & 2.51 \\
\hline 10 & Barley & 0.019 & 1.88 & 0.058 & 2.18 & 0.178 & 3.60 & 0.042 & 2.40 \\
\hline 11 & Arhar & 0.013 & 1.28 & 0.075 & 2.82 & 0.108 & 2.18 & 0.037 & 2.11 \\
\hline 12 & Cucurbit & 0.014 & 1.28 & 0.075 & 2.82 & 0.092 & 1.86 & 0.027 & 1.54 \\
\hline 13 & Onion & 0.015 & 1.48 & 0.037 & 1.39 & 0.077 & 1.55 & 0.025 & 1.42 \\
\hline 14 & Berseem & 0.008 & 0.79 & 0.024 & 0.90 & 0.018 & 0.36 & 0.013 & 0.74 \\
\hline & $\begin{array}{l}\text { Total Cropped } \\
\text { Area }\end{array}$ & 1.01 & 100 & 2.65 & 100 & 4.94 & 100 & 1.75 & 100 \\
\hline
\end{tabular}

Table.3 Per hectare investment (₹) on different size group of farms

\begin{tabular}{|c|c|c|c|c|c|}
\hline S.N. & Particulars & $\begin{array}{c}\text { Marginal } \\
\text { (below - 1ha) }\end{array}$ & $\begin{array}{c}\text { Sm44all } \\
(1-2 \text { ha })\end{array}$ & $\begin{array}{l}\text { Medium } \\
(2-4 \text { ha })\end{array}$ & $\begin{array}{l}\text { Overall } \\
\text { average }\end{array}$ \\
\hline 1 & Building & $\begin{array}{c}110581.00 \\
(53.59)\end{array}$ & $\begin{array}{c}117110.00 \\
(42.71)\end{array}$ & $\begin{array}{c}74501.00 \\
(43.70)\end{array}$ & $\begin{array}{c}104080.00 \\
(48.77) \\
\end{array}$ \\
\hline 2 & Livestock & $\begin{array}{c}59222.00 \\
(28.69)\end{array}$ & $\begin{array}{c}41741.00 \\
(15.22)\end{array}$ & $\begin{array}{c}28658.00 \\
(16.81)\end{array}$ & $\begin{array}{c}40857.00 \\
(19.14) \\
\end{array}$ \\
\hline 3 & Implements \& machineries & $\begin{array}{c}36572.00 \\
(17.22)\end{array}$ & $\begin{array}{c}115311.00 \\
(42.05)\end{array}$ & $\begin{array}{c}67299.00 \\
(39.48)\end{array}$ & $\begin{array}{c}60654.00 \\
(28.42)\end{array}$ \\
\hline & age Grand Total = & $\begin{array}{c}206374.00 \\
(100)\end{array}$ & $\begin{array}{c}274161.00 \\
(100)\end{array}$ & $\begin{array}{c}170458.00 \\
(100)\end{array}$ & $\begin{array}{c}213386.00 \\
(100)\end{array}$ \\
\hline
\end{tabular}


Table.4 Per hectare cost and income of wheat cultivation

\begin{tabular}{|c|c|c|c|c|c|c|c|c|c|}
\hline \multirow{3}{*}{$\begin{array}{c}\text { S. No. } \\
\text { (A) }\end{array}$} & \multirow{3}{*}{$\begin{array}{c}\text { Particulars } \\
\text { Costs/ expenditure }\end{array}$} & \multicolumn{8}{|c|}{ Size group of farmers cost of cultivation of sample farms } \\
\hline & & \multicolumn{2}{|c|}{ Marginal } & \multicolumn{2}{|c|}{ Small } & \multicolumn{2}{|c|}{ Medium } & \multicolumn{2}{|c|}{ Overall averege } \\
\hline & & Rs. & $\%$ & Rs. & $\%$ & Rs. & $\%$ & Rs. & $\%$ \\
\hline 1 & Total human labour & 8099.20 & 16.35 & 8186.15 & 13.04 & 5167.22 & 11.27 & 7376.18 & 15.14 \\
\hline (a) & Family labour & 5141.82 & 10.38 & 1181.80 & 2.49 & 614.54 & 1.34 & 3783.96 & 7.77 \\
\hline (b) & Hired labour & 2957.38 & 5.97 & 5004.34 & 10.54 & 4552.67 & 9.93 & 3592.22 & 7.37 \\
\hline 2 & Bullock power & - & - & - & - & - & - & - & - \\
\hline 3 & $\begin{array}{l}\text { Tractor charges } \\
\text { (machinery power) }\end{array}$ & 7869.98 & 15.89 & 7980.04 & 16.82 & 7625.24 & 16.63 & 7874.36 & 16.17 \\
\hline 4 & Cost of seed & 2939.55 & 5.93 & 2882.77 & 6.07 & 2939.79 & 6.41 & 2923.26 & 6.00 \\
\hline 5 & Manure \& ferpleyor & 7667.06 & 15.48 & 7453.07 & 15.71 & 7606.28 & 16.59 & 7610.23 & 15.62 \\
\hline 6 & Irrigation charges & 6922.39 & 13.97 & 7145.67 & 15.06 & 6868.72 & 14.98 & 6971.14 & 14.31 \\
\hline 7 & Cost protection charges & 348.34 & 0.70 & 335.94 & 0.708 & 341.63 & 0.74 & 344.76 & 0.70 \\
\hline 8 & $\begin{array}{l}\text { Interest on working } \\
\text { capital }\end{array}$ & 676.93 & 1.36 & 639.67 & 1.34 & 610.97 & 1.33 & 622.05 & 1.35 \\
\hline 9 & $\begin{array}{l}\text { Rental value of owned } \\
\text { land }\end{array}$ & 10000.00 & 20.19 & 10000.00 & 21.08 & 10000.00 & 21.82 & 10000.00 & 20.53 \\
\hline \multirow[t]{2}{*}{10} & Interest on fixed capital & 469.00 & 1.33 & 500.00 & 1.59 & 773.00 & 2.04 & 562.00 & 1.54 \\
\hline & Sub Total $=$ & 45023.45 & 90.90 & 43123.31 & 90.90 & 41659.85 & 90.90 & 44264.69 & 90.90 \\
\hline \multirow[t]{2}{*}{11} & $10 \%$ Marginal cost & 4502.34 & 9.09 & 4312.33 & 9.09 & 4165.98 & 9.09 & 4426.46 & 9.09 \\
\hline & Grand Total $=$ & 49525.79 & 1000 & 47435.54 & 100 & 45825.83 & 100 & 48691.13 & 100 \\
\hline (B) & \multicolumn{9}{|l|}{ Income } \\
\hline 12 & Cross Income & & 65454.65 & & 62652.68 & & 62178.92 & & 64487.36 \\
\hline 13 & Net Income & & 15928.86 & & 15217.18 & & 16353.09 & & 15796.23 \\
\hline 14 & Farm business income & & 26073.02 & & 31211.18 & & 31633.62 & & 27806.63 \\
\hline 15 & Family labour income & & 25573.02 & & 20711.18 & & 21133.62 & & 24006.63 \\
\hline 16 & Farm Investment income & & 20931.20 & & 30029.38 & & 31019.08 & & 24022.67 \\
\hline 17 & Cost of production Rs./q & & 1150.92 & & 1157.37 & & 1140.28 & & 1151.50 \\
\hline 18 & Yield Q/ha & & 42.15 & & 40.48 & & 39.88 & & 41.54 \\
\hline 19 & Input: output ratio & & $1: 1.32$ & & $1: 1.32$ & & 1:1.35 & & $1: 1.32$ \\
\hline
\end{tabular}

Table.5 Elasticity of production and marginal value productivity on different size group of farms

\begin{tabular}{|c|c|c|c|c|c|c|c|c|c|c|c|}
\hline \multirow[t]{2}{*}{$\begin{array}{l}\text { S. } \\
\text { No }\end{array}$} & \multirow{2}{*}{$\begin{array}{l}\text { Size of } \\
\text { group of } \\
\text { farms }\end{array}$} & \multicolumn{4}{|c|}{ Elasticity of production variables } & \multirow{2}{*}{$\begin{array}{l}\text { Sum of } \\
\text { elasticity } \\
\text { (return } \\
\text { to scale) }\end{array}$} & \multirow[t]{2}{*}{$\mathbf{R}^{2}$} & \multicolumn{4}{|c|}{$\begin{array}{l}\text { Marginal value of productivity } \\
\text { (M.V.P.) }\end{array}$} \\
\hline & & $\begin{array}{l}\mathrm{X}_{1} \\
\text { (seed) }\end{array}$ & $\begin{array}{l}\mathrm{X}_{2} \\
\text { (Manure \& } \\
\text { fertilizer) }\end{array}$ & $\begin{array}{l}\mathrm{X}_{3} \\
\text { (irrigation) }\end{array}$ & $\begin{array}{l}\mathrm{X}_{4} \\
\text { (Human labour) }\end{array}$ & & & $\begin{array}{l}\mathrm{X}_{1} \\
\text { (seed) }\end{array}$ & $\begin{array}{l}\mathrm{X}_{2} \\
\text { (Manure } \\
\& \\
\text { fertilizer) }\end{array}$ & $\begin{array}{l}\mathrm{X}_{3} \\
\text { (irrigation) }\end{array}$ & $\begin{array}{l}\mathbf{X}_{4} \\
\text { (Human } \\
\text { labour) }\end{array}$ \\
\hline 1 & $\begin{array}{l}\text { Marginal } \\
\text { (below } \\
\text { 1ha.) }\end{array}$ & $\begin{array}{l}0.008201 \\
(0.093575)\end{array}$ & $\begin{array}{l}0.136593 * * \\
(0.045737)\end{array}$ & $\begin{array}{l}0.051494 \\
(0.056022)\end{array}$ & $\begin{array}{l}0.755202 * * \\
0.140212\end{array}$ & 0.951491 & 0.9643395 & 7.639 & 1.320 & 0.499 & 1.187 \\
\hline 2 & $\begin{array}{l}\text { Small } \\
\text { (1-2 ha. })\end{array}$ & $\begin{array}{l}0.190959 * * \\
(0.047987)\end{array}$ & $\begin{array}{l}0.030972 \\
(0.196622)\end{array}$ & $\begin{array}{l}0.026311 \\
(0.068134)\end{array}$ & $\begin{array}{l}0.603483 * * \\
(0.172928)\end{array}$ & 0.851731 & 0.954158 & 8.331 & 0.585 & 0.405 & 1.322 \\
\hline 3 & $\begin{array}{l}\text { Medium } \\
\text { (2-4 ha.) }\end{array}$ & $\begin{array}{l}0.31701 * * \\
(0.096206)\end{array}$ & $\begin{array}{l}0.168892 \\
(0.201953)\end{array}$ & $\begin{array}{l}0.036779 \\
(0.06372)\end{array}$ & $\begin{array}{l}0.0440492 * * \\
(0.121771)\end{array}$ & 0.963173 & 0.954148 & 11.622 & 3.399 & 0.099 & 1.718 \\
\hline
\end{tabular}

**Significant at $1 \%$ level of probability and at (n-k-1) d.f. *Significant at $5 \%$ level of probability and at n-k-1 d.f. 
Other crops which had the considerable place in cropping pattern were Bajra 25.14, Maize 6.97 percent, Paddy 6.97 percent. Potato, Moong, Urd, Jowar, Mustard, Gram, Barley and Arhar each were occupying the more than 6 percent to gross cropped area, respectively.

\section{Investment of farm assets}

Per hectare investment by different categories of farmers on farm like Building, Livestock and implement and machineries are presented in Table 3. it is revealed from the table that the average expenditure an farm assets on overall farm was Rs. 213386.00 a major part of this expenditure was occurred on building constructional 48.77 percent of total, and the next important head of expenditure was implements and machineries having 28.42 percent of total investment. The expenditure incurred on livestock was found to 19.14 percent of the total respectively farm size grouped wise investment came to ₹ 206374.00, ₹ 244161.00 and ₹ 170458.00 corresponding to marginal, small and medium size group of farm.

\section{Cost and returns}

\section{Cost}

Per hectare cost return from the cultivation of wheat crop on different categories of farms have been presented in Table 4 It is obvious from the table that, on an overall average per hectare cost of cultivation of wheat carry to ₹ 48691.13 per ha which was maximum to ₹ 49525.79 on marginal farms followed by small farms and medium farms corresponding to ₹ 47435.54 and ₹ 45825.83, respectively. The cost of cultivation was maximum on marginal sample farms due to more expenditure occurred on human labour and tractor chargers as compared to other categories of farms. It was also observed from the table that cost of cultivation showed positive relationship with the size group of farms.

\section{Returns}

It is observed from the table that per hectare gross income was maximum to be ₹ 65454.65 on marginal forms followed by small and medium farms corresponding to ₹ 62652.68 and ₹ 62178.92, respectively in respect of all farms. Average gross income came to Rs. 64487.36 however, other income measures like Net Income ₹ 15796.23 Farm Business Income ₹ 27806.63, Family Labour Income ₹ 24022.67 and Farm Investment Income ₹ 24006.63 were also assessed and trend was showing positive relationship in the contest of various measures of income with size of farms. Similar study of wheat has been conducted by Raghuwanshi et al., (1999).

Per quintal cost of production of wheat was calculated on the basis of highest to ₹ 1157.37 on small farms followed by marginal and medium farms corresponding value were ₹ 1150.92 and ₹ 1140.28 , respectively, along with ₹ 1151.50 per quintal on all average farms ₹ 41.54 quintal per hectare on an average yield. The overall average inputoutput ratio was found to 1:1.32 which had the direct relationship with size of holding.

Among the factors considered under analysis, see, manure \& fertilizer, human labour and irrigation jointly explained 96.43, 95.41 and 95.41 pre cent variation accused independent variable on marginal, small and medium farms, respectively. It is also revealed form the table that was statistically significant at 1 per cent level of probability in all size groups of farms.

Overall average size of holding in the study area was $0.473,1.244$, and 2.258 hectare in marginal, small and medium size of farms respectively whereas overall average of 
holding size was 0.818 hectares (Table 5). The cropping pattern shows that wheat was first important crop which covered maximum area wheat 32.05 per cent followed by bajra 25.14 per cent maize 7.25 , barely 2.4 , Arhar 2.11, cucurbits 1.54, onion 1.42, and barseem 0.74 percent to gross cropped area (kharif, rabi and zaid) respectively. Cropping intensity was 216.04 percent overall average, cropping intensity decreased with the increase in the size of holding. The maximum total cost was recorded on marginal farms (₹ 49525.79) due to heavy expenditure on human labour, irrigation and income and fertilizer the per quintal cost of production of wheat overall farm are ₹ 1151.50 whereas cost of production ₹ 4450.92, ₹ 1157.37 and ₹ 1140.28 of marginal, small and medium farms, respectively. Input-output ratio on the basis of overall 1:1.32, 1:1.32 and 1:1.35 respectively. The cultivation of wheat was characterized by decreasing returns to scale on each farm situation.

\section{References}

Agricultural Statistics at a Glance. (2015). New Delhi: Ministry of Agriculture and Farmers' Welfare.
Cobb, C.W. and Douglas, P.H. (1928). A Theory of Production. American Economic Review. 18 (Supplement): 139-165. Retrieved 26 September 2016.

Khan, B.A. and Alam, S.A. (1988). Impact technological changes on size productivity relationship and resources use efficiency in Kashmir Agriculture. Agricultural Situation in India, 43 (4): 301-307.

Lal, S.K. (1994). Growth and resource productivity in Bihar Agriculture. Agricultural Marketing. 2 (2): 107-111.

Raghuvanshi, R.S.; Awasthi, P.K. and Sharma, P. (1999). Resource use efficiency in wheat cultivation. Indian Journal Agricultural Research, 33 (7): 65-71.

Rajput, A.M., Saxena, K.K. and Bisoniya, K.S. (2001). Profitability of wheat varieties in Indaur, (M.P.) Crops Research Hissar, 21 (1): 27-29.

Sharma and Shusil (2005). Examined the resource use efficiency of wheat farms in Hissar district of Haryana. Journal Research, (6): 20-28.

Singh, U.K. Gupta, D.D. and Singh H. (1992). Input use-efficiency in wheat crop in Haryana. Indian Journal Agricultural Economics, (3): 500-501.

\section{How to cite this article:}

Kushwaha, R.R., K.K. Mourya, R.R. Verma, Bhim Singh, Sugriv Kumar Maurya, Neeraj Kumar and Sarvesh Kumar. 2018. Resource Use Efficiency on Wheat Cultivation in Auraiya District of Western Uttar Pradesh, India. Int.J.Curr.Microbiol.App.Sci. 7(06): 1054-1060. doi: https://doi.org/10.20546/ijcmas.2018.706.125 